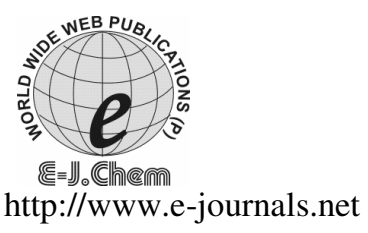

\title{
Highly Sensetive Reaction for the Estimation of Carbaryl Using 4-4' - Diaminodiphenyl Sulfone in Environmental Samples
}

\author{
BESAGARAHALLY L. BHASKARA and PADMARAJAIAH NAGARAJA* \\ Department of Chemistry \\ University of Mysore, Manasagangotri, \\ Mysore - 570 006, India
}

Received 8 June 2006; Accepted 31 July 2006.

\begin{abstract}
A rapid, sensitive Spectrophotometric method for the determination of ultra trace amount of carbaryl (1- Napthyl-N- Methyl Carbamate) is proposed. The method is based on an alkali hydrolysis of carbaryl in the presence of methanolic $\mathrm{KOH}$, followed by coupling with diazotized $4-4^{1}$ - diaminodiphenyl sulfone in an alkaline medium. The water soluble pink dye obtained shows an absorption maximum at $540 \mathrm{~nm}$. The system obeys Beer's law over the range of 0.06-2.0 $\mu \mathrm{g}$ $\mathrm{ml}^{-1}$. The absorptivity of the coloured product is $7.014 \times 10^{4} 1 \mathrm{~mol}^{-1} \mathrm{~cm}^{-1}$ and the developed colour is stable for 48h.The detection limit of Carbaryl is $0.0102 \mu \mathrm{g} \mathrm{ml}^{-1}$. This method is a very good alternative tool and it can be used successfully for the determination of carbaryl residue in environmental water and grain samples.
\end{abstract}

Keywords: Spectrophotometric, carbaryl and dapsone, higly sensitive reaction.

\section{Introduction}

Carbaryl (1-Naphthyl -N-Methyl carbamate) is a broad-spectrum pesticide, extensively used as contact and systemic insecticide on agricultural products, introduced in the year 
1957. Even though it is a cholinesterase inhibitor, it has been accepted to have low mammalian toxicity. This type of concept is due to upon chemical hydrolysis and biodegradation carbaryl producing metabolites, among which 1-Naphthol is a major product which does not accumulate in the body, but it excretes in urine and faeces. Despite these merits, recent data shows that some adverse effects have also been reported. It includes, alteration of liver microsomal enzymes ${ }^{1}$, sub chronic neurotoxicity ${ }^{2}$, changes on immunological function in in-vitro culture ${ }^{3}$ and the combination of cyano- bacteria with Carbaryl and 1-Naphthol showing more toxicity when compared to cyano- bacteria alone ${ }^{4}$.

A detailed survey of literature reveals few methods including chromatographic ${ }^{5-8}$, immunoassay ${ }^{9-10}$ and Spectrophotometric methods ${ }^{11-19}$ are reported. But these reported methods are having their own demerits; example HPLC methods are very expensive due to high cost of solvents and other spectrophotometric methods are of low sensitivity and multiple steps involved. Therefore the present paper describes simple, sensitive and rapid method for carbaryl estimation. It involves coupling of carbaryl with diazotized dapsone in $\mathrm{KOH}$ media.

\section{Experimental}

\section{Materials and methods}

SYSTRONICS SPECTROPHOTOMETER - 106 Model with 10mm matched quartz cells was used throughout the spectral measurement.

\section{Reagents}

Analytical grade sample of Carbaryl pesticide (99.9\%) was obtained from Bayer India Ltd. India. 4-4 $4^{\mathrm{I}}$ - diaminodiphenyl sulfone (dapsone) was obtained from Merk (Germany), Pesticide grade methanol and acetone were obtained from Sigma, (USA), Sodium nitrite, Potassium hydroxide, Sulphamic acid, were from BDH, AnalR. Double distilled water was used throughout the experiment.

A stock solution of carbaryl $\left(1000 \mu \mathrm{g} \mathrm{ml}^{-1}\right)$ was prepared by dissolving $100 \mathrm{mg}$ of carbaryl in acetone in $100 \mathrm{ml}$ calibrated flask and diluted with acetone. $5 \mathrm{M} \mathrm{KOH}$ solution was prepared in methanol. Sodium nitrate $1.0 \%$ solution in water, $0.2 \%$ dapsone was prepared in $1 \mathrm{M}$ hydrochloric acid, $2 \%$ Sulphamic acid was prepared in water.

\section{Recommended procedure}

An aliquot of the standard solution of carbaryl containing 1.5-50 $\mu \mathrm{g}$ of carbaryl was transferred into a series of $25 \mathrm{ml}$ of calibrated flasks, $5 \mathrm{ml}$ of $5 \mathrm{M} \mathrm{KOH}$ solution was added to each flasks and allowed to stand for $5 \mathrm{~min}$ for complete hydrolysis, followed by the addition of $2 \mathrm{ml}$ of $0.2 \%$ dapsone, $2 \mathrm{ml}$ of $1.0 \%$ sodium nitrate and $2 \mathrm{ml}$ of $2 \%$ Sulphamic acid and kept aside for $2 \mathrm{~min}$ to complete the reaction with occasional shaking. Pink coloured azo dye was formed. Dilution was made with water up to the mark and the absorbance was recorded at $540 \mathrm{~nm}$ against the corresponding reagent blank and calibration graph was constructed.

\section{Results and Discussion}

\section{Spectral characteristics}

The proposed method involves the formation of a pink azo dye having $\lambda_{\max }$ of $540 \mathrm{~nm}$. The reagent blank had negligible absorption at this wavelength. The absorption spectrum of the coloured dye and the corresponding reagent blank are given in the Figure 1. 


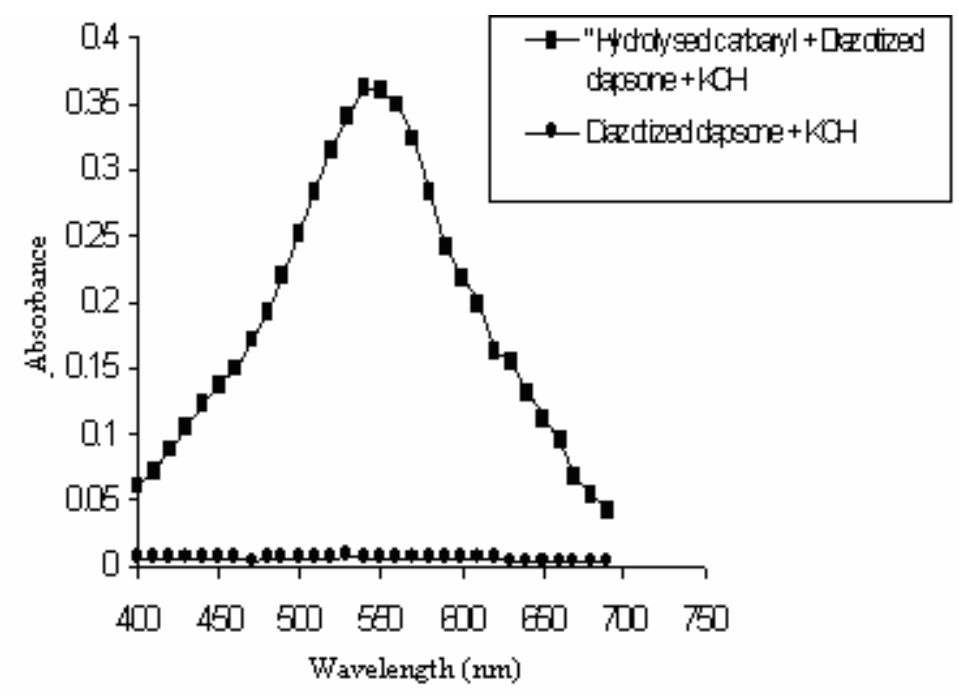

Figure 1. Absorption spectra of the reaction Product of Hydrolyzed Carbaryl and Reagent blank

\section{Optimization of the reagent concentration}

Various concentration and volume ranges for all the reagents were studied in detail. It was found that dapsone in the range of $1-2 \mathrm{ml}$, sodium nitrite in the range of $0.5-4.0 \mathrm{ml}$, sulfamic acid in the range of $0.5-4.0 \mathrm{ml}$ and $\mathrm{KOH} 2-5.0 \mathrm{ml}$ were necessary to obtain a stable pink colored product with maximum colour intensity.

\section{Quantification}

Adherence to Beer's law by the coloured product of diazotized dapsone with hydrolyzed carbaryl (sevin) was determined by measuring the absorbance at appropriate wavelength $(540 \mathrm{~nm})$ for a set of solutions containing varying amounts of analyte and specified amounts of reagents against colorless reagent blank. Beer's law was obeyed over the hydrolyzed carbaryl range of $0.06-2.0 \mu \mathrm{g} \mathrm{ml}^{-1}$. Limit of quantification (LOQ) is determined by taking the ratio of standard deviation $(\sigma)$ of the blank with respect to water and the slope of the calibration curve (a) multiplied by a factor 10. LOQ is approximately 3.3 times the limit of detection (LOD). Naturally, the LOQ slightly crosses the lower limit of the Beer's law range. But LOD is well below the lower limit of the Beer's law range. The upper limit of the Beer-Lambert range is determined by a plot of absorbance against concentration at the value of $\lambda$ max. Beyond this limit, the correlation results were really affected. Hence, the measurements were excluded above these limits to keep the relationship linear. The optical characteristics and precision data are given in Table 1 .

\section{Precision and Accuracy}

The precision of the proposed method was ascertained from the absorbance values of five replicates. The percentage relative standard deviation was calculated for the proposed method. The accuracy of the method was confirmed by recovery methods. 
Table 1. Optical characteristics and precision data for the product

\begin{tabular}{|c|c|}
\hline Optical parameters & Dapsone method \\
\hline Colour & Pink \\
\hline$\lambda_{\max }(\mathrm{nm})$ & 540 \\
\hline Stability (h) & 48 \\
\hline Beer's law range $\mu \mathrm{g} \mathrm{ml}^{-1}$ & $0.06-2.0$ \\
\hline Molar absorptivity $1 \mathrm{~mol}^{-1} \mathrm{~cm}^{-1}$ & $7.014 \times 10^{4}$ \\
\hline Sandell's Sensitivity $\mathrm{ng} \mathrm{cm}^{-2}$ & 2.8 \\
\hline Limit of detection (LOD) $\mu \mathrm{g} \mathrm{ml}^{-1}$ & 0.0102 \\
\hline Limit of Quantification (LOQ) $\mu \mathrm{g} \mathrm{ml}^{-1}$ & 0.342 \\
\hline \multicolumn{2}{|l|}{ Regression equation $\mathrm{Y}^{*}$} \\
\hline Slope (a) & 0.349 \\
\hline Intercept (b) & 0.0001 \\
\hline Correlation Coefficient $(r)^{\mathrm{b}}$ & 0.9998 \\
\hline Relative standard deviation $(\%)^{\mathrm{b}}$ & 0.00114 \\
\hline Range of error( $95 \%$ ) confidence level & 0.248 \\
\hline
\end{tabular}

\section{Proposed reaction mechanism}

Carbaryl undergoes an alkali hydrolysis in the presence of alcoholic $\mathrm{KOH}$ to gives $\alpha$ - Naphthol, which coupled with Diazotized dapsone to give water soluble pink azo dye having maximum absorption at 540nm. Tentative reaction mechanism is shown in Scheme1.

\section{Effect of temperature and colour stability}

Under the optimized condition, $5 \mathrm{~min}$ was given for complete colour development. The intensity of the colour developed was stable at the temperature range from $20^{\circ} \mathrm{C}$ to $70{ }^{\circ} \mathrm{C}$ and up to $48 \mathrm{~h}$ at room temperature.

\section{Effect of Foreign ions}

Under the diazotized condition reactions used, other pesticides and other common expedients which are present in water were studied thoroughly. It is significant to note that various common ions did not interfere even when added in excess to a known amount of hydrolyzed carbaryl. Table 2 shows the results of interference on the determination of carbaryl. An error of $2 \%$ in the absorbance reading was considered tolerable.

\section{Recovery of the carbaryl residues from spiked water samples}

Water samples $(100 \mathrm{ml})$ spiked with known amount of carbaryl $\left(\mu \mathrm{g} \mathrm{ml}^{-1}\right)$ is added, the $\mathrm{pH}$ of these samples adjusted to 3-4 with $2 \mathrm{M}$ Sulphuric acid. The mixture was transferred into a separating funnel and insecticide was extracted using approximately $15 \mathrm{ml}$ of Chloroform in each occasion till complete extraction. The combined extracts were washed with $2 \mathrm{ml}$ of $0.1 \mathrm{M}$ potassium Carbonate to break any emulsion formed during the extraction. The extracted insecticide was dried over anhydrous sodium sulphate. Chloroform was evaporated and residue was dissolved in methanol. Determination was carried out by above procedure and data are shown in Table 3. 
<smiles>O=C(O)c1cccc2ccccc12</smiles>

Carbaryl<smiles>O[131I]c1ccc2cccc(O)c2c1</smiles>

naphthol

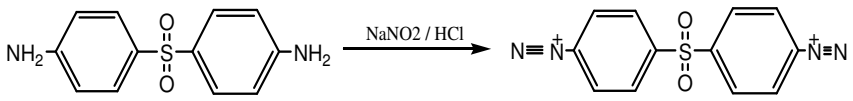

Dapsone

Diazotized Dapsone

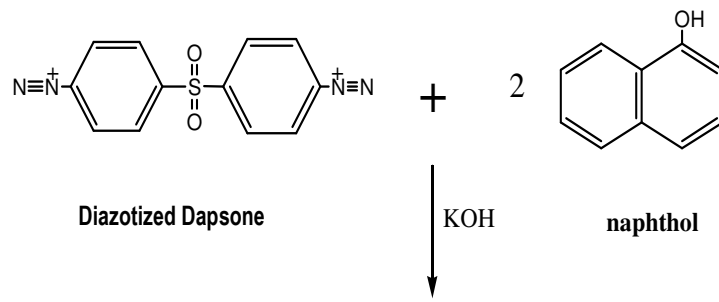<smiles>O=S(=O)(c1ccc(N=Nc2ccc3ccccc3c2O)cc1)c1ccc(N=Nc2ccc3ccccc3c2O)cc1</smiles>

Pink Azo Dye

Proposed reaction mechanism scheme 1

Table 2. Effect of excipients on the determination of carbaryl

\begin{tabular}{lll}
\hline Excipients & $\begin{array}{l}\text { Amount of excipients } \\
\text { added } \mu \mathrm{g} \mathrm{ml}^{-1}\end{array}$ & $\begin{array}{l}\text { Mean recovery } \\
\text { in \% }\end{array}$ \\
\hline Parathion & 5000 & 99.50 \\
Malathion & 3000 & 99.70 \\
Chloride & 200 & 100.10 \\
$\mathrm{Lead}\left(\mathrm{Pb}^{2+}\right)$ & 400 & 99.08 \\
$\mathrm{Ca}^{2+}$ & 200 & 99.50 \\
$\mathrm{Mg}^{2+}$ & 250 & 99.45 \\
$\mathrm{SO}_{4}{ }^{2-}$ & 220 & 98.99 \\
$\mathrm{NO}^{2-}$ & 150 & 99.85 \\
$\mathrm{CO}_{3}{ }^{2-}$ & 230 & 100.06 \\
\hline
\end{tabular}


Table 3. Recovery of carbaryl residue from spiked water samples

\begin{tabular}{lllc}
\hline Water sample & $\begin{array}{l}\text { Carbaryl added } \\
\mu \mathrm{gml}^{-1}\end{array}$ & $\begin{array}{l}\text { Carbaryl found } \\
\mu \mathrm{gml}^{-1}\end{array}$ & $\begin{array}{l}\text { Mean Recovery } \\
\text { in } \% \text { and } \pm \mathrm{SD}^{\mathrm{b}}\end{array}$ \\
\hline Well water (1) & 1.0 & 0.97 & $97.00 \pm 0.43$ \\
Well water (2) & 0.8 & 0.81 & $101.25 \pm 0.39$ \\
River water(1) & 0.5 & 0.48 & $96.00 \pm 0.48$ \\
River water(2) & 1.5 & 1.46 & $97.33 \pm 0.45$ \\
Tap water (1) & 1.0 & 0.99 & $99.00 \pm 0.51$ \\
Tap water (2) & 0.5 & 0.51 & $102.00 \pm 0.42$ \\
${ }_{\mathrm{b}}^{\mathrm{n}=5}$ & & &
\end{tabular}

\section{Recovery of Carbaryl residues from grain samples}

Grain samples such as wheat and rice were taken of about $20 \mathrm{~g}$ each in a warming blender and blended for $15 \mathrm{~min}$ with $50 \mathrm{ml}$ of chloroform. These samples were fortified with carbaryl in methanol and again blended for about $5 \mathrm{~min}$. Chloroform was filtered and evaporated on water bath. Thus obtained residue was dissolved in methanol and estimation of carbaryl was carried out by proposed method and results are presented in the Table 4.

Table 4. Recovery of Carbaryl residues from grain samples

\begin{tabular}{rccc}
\hline Samples & $\begin{array}{c}\text { Amount of carbaryl } \\
\text { added } \mu \mathrm{gml}^{-1}\end{array}$ & $\begin{array}{c}\text { Amount of carbaryl } \\
\text { found } \mu \mathrm{gml}^{-1}\end{array}$ & $\begin{array}{c}\text { Mean recovery } \\
\text { in } \% \text { and } \pm \mathrm{SD}^{\mathrm{b}}\end{array}$ \\
I wheat 1 & 0.75 & 0.74 & $98.66 \pm 0.45$ \\
2 & 1.0 & 0.98 & $98.00 \pm 0.52$ \\
3 & 1.25 & 1.23 & $98.44 \pm 0.35$ \\
II Rice 1 & 1.0 & 1.01 & $101.00 \pm 0.35$ \\
2 & 1.5 & 1.47 & $98.00 \pm 0.50$ \\
3 & 0.8 & 0.81 & $101.25 \pm 0.42$ \\
\hline${ }^{\mathrm{b}} \mathrm{n}=5$ & &
\end{tabular}

Table 5. Comparison of Other Spectrophotometric methods with proposed method

\begin{tabular}{|c|c|c|c|}
\hline Methods & $\begin{array}{l}\lambda_{\max } \\
\mathrm{nm}\end{array}$ & $\begin{array}{l}\text { Beer's law range } \mu \mathrm{g} \mathrm{ml}^{-1} \text { and } \\
\text { Molar absorptivity. } 1 \mathrm{~mol}^{-1} \mathrm{~cm}^{-1}\end{array}$ & Remarks \\
\hline $\mathrm{P}-{\text { Aminobenzoic } \text { Acid }^{(16)}}$ & 470 & $0.1-0.8$ and $2.00 \times 10^{4}$ & $\begin{array}{l}\text { Extraction is necessary } \\
\text { Dye stability up to } 24 \mathrm{~h}\end{array}$ \\
\hline $\begin{array}{l}\text { P-Dimethylphenylene } \\
\text { Diamine dihydrochloride }\end{array}$ & 600 & $0.7-8.0$ and $1.41 \times 10^{4}$ & Reagent itself toxic \\
\hline P- Aminophenol ${ }^{(15)}$ & 600 & $0.8-10$ and $1.33 \times 10^{4}$ & Not much sensitive \\
\hline 2- Amino 4- Nitrophenol ${ }^{(19)}$ & 520 & $0.4-10$ and $3.018 \times 10^{4}$ & $\begin{array}{l}\text { Moderately sensitive } \\
\text { Dye stable up to } 24 \mathrm{~h}\end{array}$ \\
\hline 2,4 - dimethoxy aniline ${ }^{(19)}$ & 505 & $0.4-10$ and $3.42 \times 10^{4}$ & $\begin{array}{l}\text { Moderately sensitive } \\
\text { Dye stable up to } 10 \mathrm{~h}\end{array}$ \\
\hline $\begin{array}{l}\text { 4-4-diaminodiphenylsulfone } \\
\text { (Present method) }\end{array}$ & 540 & $0.06-2.0$ and $7.014 \times 10^{4}$ & $\begin{array}{l}\text { Highly sensitive } \\
\text { Dye stable up to } 48 \mathrm{~h}\end{array}$ \\
\hline
\end{tabular}




\section{Comparison of Other Spectrophotometric methods with proposed method}

The data presented in the Table 5 suggests the present method is very sensitive and facile when compare with other officially reported method.

\section{Conclusion}

The proposed spectrophotometric method is simple to perform, cheaper and sensitive when compared to many other existing methods which are shown in Table 5. The sensitivity, simplicity, temperature independence and stability of the colored product are the advantages of this method. This method can be used to detect $0.0102 \mu \mathrm{g} \mathrm{ml}^{-1}$ and quantitatively detect $0.0342 \mu \mathrm{g} \mathrm{ml}^{-1}$ of carbaryl and does not involve extraction step and the use of carcinogenic solvents. The proposed method does not entail any stringent experimental variables which affect the reliability of the results. From the recovery studies it comes to know that this method can serve as an alternative method for determining carbaryl residues in various environmental samples.

\section{Acknowledgements}

One of the authors (B.L.B.) thanks the University of Mysore for providing the laboratory facilities.

\section{References}

1. Lechner D W and Abdul Rahman M S, Arch. Environ.Contam. Toxical, 1985,14, 451.

2. Branch R A and Jacpz E, J. Med., 1986, 80, 741.

3. Bavari R A, Casale G P, Gold R E, and Vitzhum Fundam E F, Appl.Toxicol., 1991, 17,61 .

4. Megharaj M, Rao A P, Rao A S and Venkateshvarulu K, Agri. Ecosyst.Environ., 1990, 31, 293

5. Berardinis M De and Jr Wargin W A, J. Chromotogr .1982, 246, 89.

6. Hargreaves P A, Melksham K, J. Pestic.Sci. 1983, 14, 347

7. Ward S A, May G and Branch R A, J. Chromotogr. 1987, 388. 462

8. Strait J R, Thornwall G C and Marion Ehrich, J. Agri food. Chem. 1991, 39, 710.

9. Petra Karner M, Marco M P and Hammock B D, J. Agric. Food. Chem. 1994, 42, 934.

10. Marco M P, Serge Chirm, Jordi Gason, Hammock B D and Damia Bracel, Analytica Chimica Acta, 1995, 311, 319.

11. Miskus R, Gordon H T and George D A, J. Agric. Food. Chem., 1959, 7, 613.

12. Handa S K and Dikshit A K , Analyst 1974, July,1185

13. Rangaswamy J R and Majumdar S K, J. Assoc. Off. Anal. Chem., 1974, 57, 592.

14. Voneseh E E and Maria H C K de Riveros, J. AOAC 1991, 54,128.

15. Sastry C S P , ViJaya D and Manyda D S , Analyst 1987, 17, 75.

16. Vikta Agarwal and Gupta V K, J. Indian Chem. Soc. 1992, 69, 574.

17. Sastry C S P and ViJaya D, Talanta, 1987, 34, 372.

18. Cassela R J, Garrigues S, Santelli R E and La Guradia M De, Talanta 2000, 52, 712.

19. Manjubhashini A B, Raman G K, Suresh Kumar A and Chiranjeevi P, Talanta 2003, 59, 1015. 


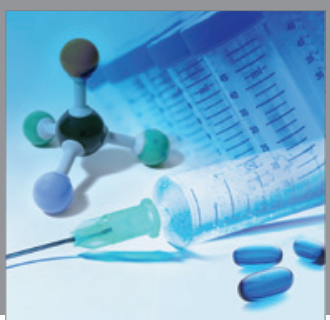

International Journal of

Medicinal Chemistry

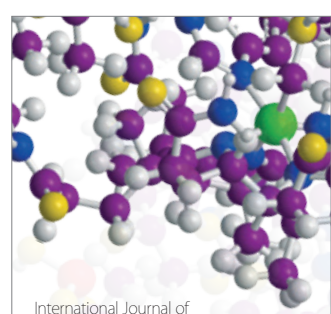

Carbohydrate Chemistry

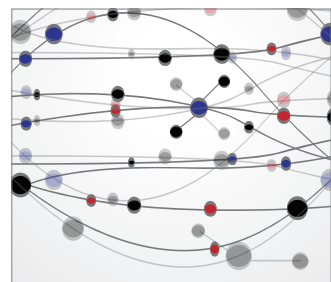

The Scientific World Journal
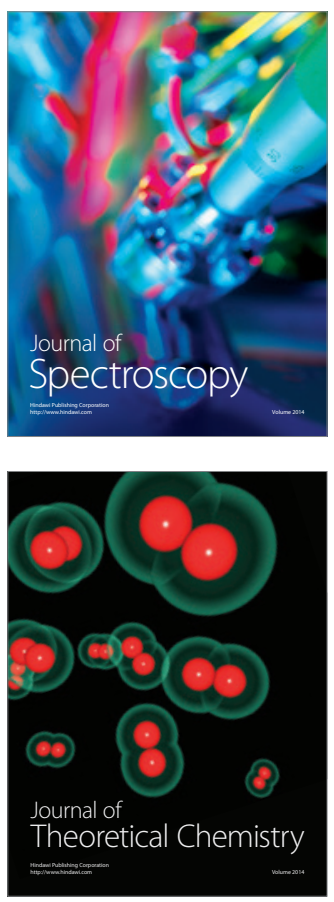
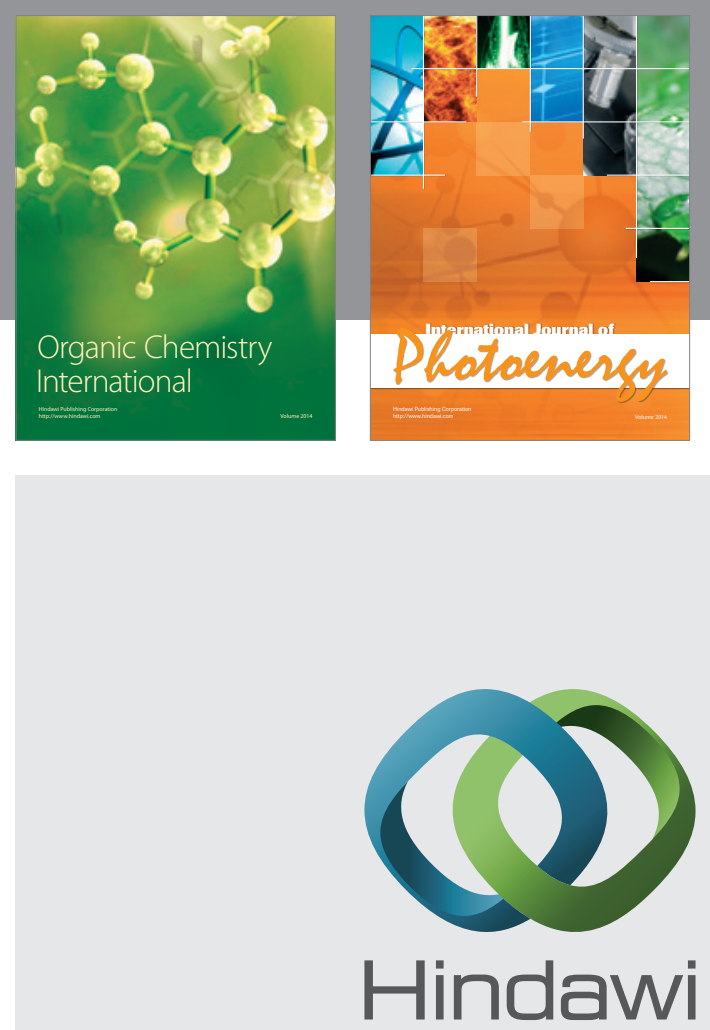

Submit your manuscripts at

http://www.hindawi.com
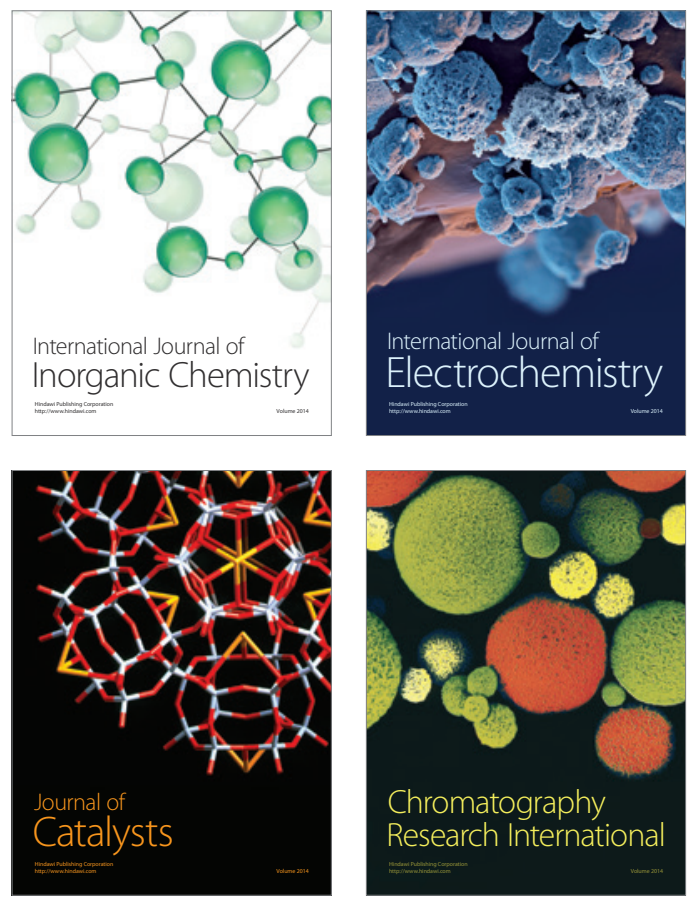
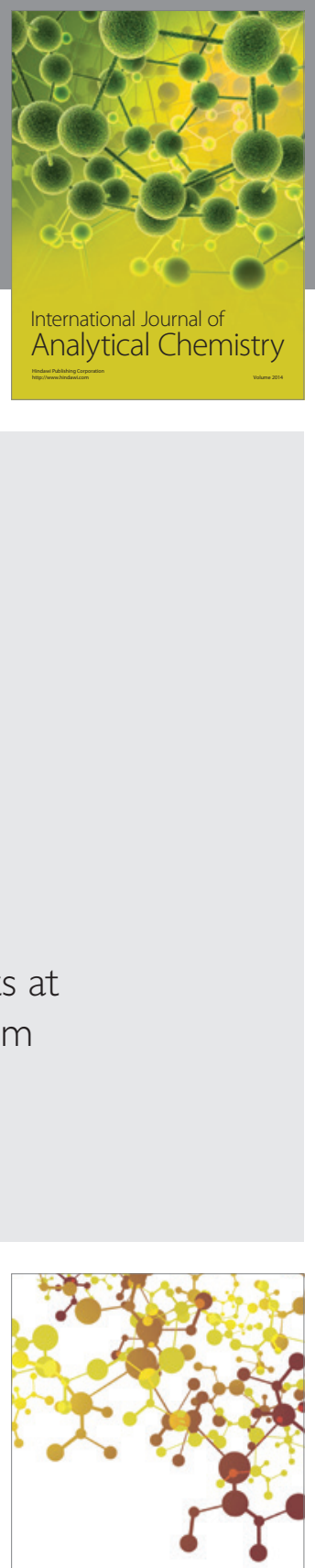

Journal of

Applied Chemistry
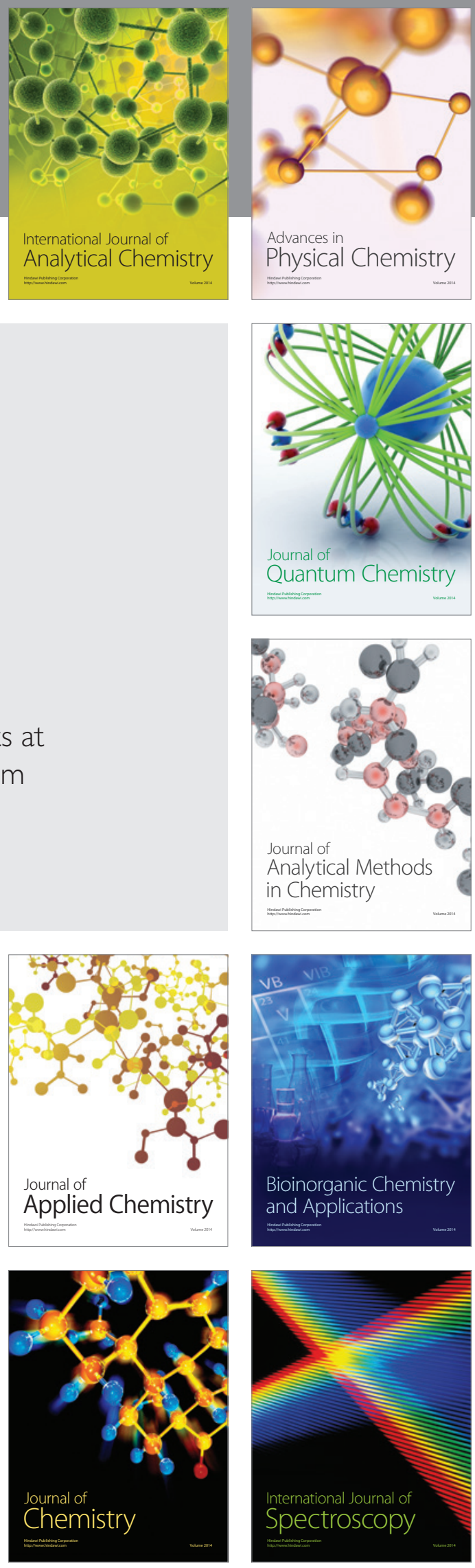